Muskett, Judith A. and Village, Andrew

ORCID: https://orcid.org/0000-0002-2174-8822 (2016) Action learning sets and social capital. Ameliorating the burden of clergy isolation in one rural diocese. Action Learning: Research and Practice, 13 (3). pp. 219-234.

Downloaded from: http://ray.yorksj.ac.uk/id/eprint/1623/

The version presented here may differ from the published version or version of record. If you intend to cite from the work you are advised to consult the publisher's version: http://dx.doi.org/10.1080/14767333.2016.1211091

Research at York St John (RaY) is an institutional repository. It supports the principles of open access by making the research outputs of the University available in digital form. Copyright of the items stored in RaY reside with the authors and/or other copyright owners. Users may access full text items free of charge, and may download a copy for private study or non-commercial research. For further reuse terms, see licence terms governing individual outputs. Institutional Repository Policy Statement

\title{
RaY
}

Research at the University of York St John

For more information please contact RaY at ray@yorksj.ac.uk 


\section{Action learning sets and social capital. Ameliorating the burden of clergy isolation in one rural diocese.}

Rural clergy often lack colleagues and may struggle with isolation, especially if over-extended in multi-parish benefices. Theory suggests this sense of isolation could be addressed by launching clergy action learning sets, which have the potential to establish a peer support network through the formation of social capital as a by-product of the pedagogical process. This case study looks at the effect of action learning set membership upon clergy involved in a new ministry development programme in one rural Church of England diocese. Markers of social capital (networks, norms and social trust) were found among set members, some of whom were prepared to draw on the new resource for assistance with problems, while others were ready to support such colleagues. Pre-existing support networks were one reason for clergy not intending to capitalize on the new links; another was the geographically dispersed set memberships.

Geography may militate against exploiting social capital, but a distance of many miles between priest and trusted confidant can be advantageous. The study demonstrates that the notion that social capital formed through action learning will ameliorate isolation among some geographically scattered clergy is grounded not only in theory but also in practice.

Keywords: action learning, deanery chapters, isolation, rural clergy, social capital. 


\section{Introduction}

Ministering in locations remote from the next incumbent, rural clergy often lack colleagues and may struggle with a sense of isolation (Paul 1964; Rolph et al. 2014), especially if overextended in multi-parish benefices (Francis and Brewster, 2012). The problem may be exacerbated by the fact that, in terms of psychological type, Anglican clergy (both men and women) tend to have a clear preference for introversion over extraversion (see Watt and Voas, 2015 for a summary of the findings of recent studies). The introvert is typically introspective, reserved and distant to all but intimate friends (Eysenck and Eysenck, 1991). Introvert clergy have been found to experience higher levels of stress in relation to the burden of isolation (Francis, Laycock, and Brewster, 2015); and of particular concern in that respect may be some evidence that rural clergy are significantly more introverted than clergy serving in non-rural areas (Francis, Smith and Robbins, 2004).

Isolation can have a detrimental effect on clergy health (Francis, Laycock, and Brewster 2015), so the challenge for church dioceses is to find ways to address structural issues associated with isolation. A clue may be found in a study of barriers to isolated clergy in the U.S. developing and maintaining close professional relationships (Staley et al. 2013). To combat isolation, interviewees' strategies included: being intentional about making time for meeting others, participation in groups, and being able to communicate openly and allow for vulnerability (p. 852). A conspicuous forum with the capacity to satisfy such needs is the Deanery Chapter ${ }^{1}$, where rural clergy from a number of adjoining parishes gather regularly 'for fellowship and mutual support' in meetings chaired by the respective Rural Dean (Archbishops' Council 2011, 2). Yet, amid the pleasantries and routine exchanges at chapter meetings there can be superficiality (Eatock 1993) and competitiveness (Platten 2005). Such a culture can lead clergy to question whether attendance is worthwhile (Eatock 1993). So, 
might there be an alternative approach to combat debilitating isolation experienced in rural ministry?

Theory suggests that, on the basis that strategies such as those identified by Staley and colleagues (2013) would be consistent with the practice of action learning to which the process of social exchange in sets is fundamental (Revans 2011), an action learning intervention may have the capacity to ameliorate the sense of isolation experienced by rural clergy (Muskett 2016). Social capital forged among set members as a by-product of the pedagogical process could have a significant impact by creating a viable and enduring peer support network. Even in circumstances where regular face-to-face contact is especially onerous owing to the time and distance involved in ongoing meetings, a network forged via action learning could be sustained by what Moss (2009) termed 'cyber-konōnia'.

Action learning is already in use among some clergy of the Church of England, which is facing a period of rapid change and needing to adapt to decreasing numbers of affiliates and worshippers. Given Revans’ (2011) prescription that adaptation in a rapidly changing context is achieved through learning, it is unsurprising that this pedagogical approach has been adopted. Peer-reviewed empirical research has yet to assess the impacts, but recent church-sponsored reports reveal positive feedback on action learning within leadership development programmes in several dioceses (Cornies 2014) and with bishops, deans and future Church leaders (Church of England 2014).

\section{Social capital}

The argument that action learning has the potential to mitigate the sense of isolation in rural ministry rests on the assumption, implied by the writings of Revans (founder of the pedagogical approach) and those of his followers (Pedler and Attwood 2011), that action 
learning can generate social capital while developing human capital (embodied in the skills and knowledge acquired by individuals).

Social capital is a concept that seeks to describe the value of social networks. Criticized as ‘one of our trendiest terms’ (Farr 2004, 6) and described as merely the 'repackaging of long-established sociological processes' (Pahl 2000, 159), social capital has also been praised as the 'most important and exciting concept to emerge out of the social sciences in fifty years' (Halpern 2005, 1) and recognized as 'one of the most popular exports from sociological theory into everyday language’ (Portes 1998, 2). There is a lack of consensus on its definition, but networks play a crucial role. Bourdieu defined social capital as 'the sum of the resources, actual or virtual, that accrue to an individual or a group by virtue of possessing a durable network of more or less institutionalized relationships of mutual acquaintance and recognition’ (Bourdieu and Wacquant 1992, 119). Putnam (1995, 67) anchored social capital in 'features of social organization such as networks, norms, and social trust that facilitate coordination and cooperation for mutual benefit'; but his subsequent shorthand definition of social capital shifted to 'social networks and the norms of reciprocity associated with them' (Putnam and Goss 2002, 3), thus subsuming trust within the norms. There is debate around whether trust is in reality a source or consequence of social capital. A two-way interaction exists between trust and co-operation (Nahapiet and Ghoshal 1998), so identifying which way causation flows in the case of trust is not straightforward (Newton 1999). To avoid tautology, trust is excluded from some definitions (Lorenzen 2007; Woolcock 2001). Nonetheless, social trust remains a primary indicator of social capital in national/cross-national surveys (such as the European Values Study and the World Values Survey) and surveys in religious settings (E. Williams 2008).

Debate also ensues over the precise location of social capital. Coleman (1990, 302) claimed it 'inheres in the structure of relations between persons and among persons'. Like 
Putnam (1995), Coleman placed emphasis on the resource being the property of communities. However, regarding social capital as a resource vested in a whole group or organization, rather than in its individual members, was criticized as 'conceptual stretch' (Portes 1998, 3). Brehm and Rahn (1997) argued it is an individual resource, and that the attitudes and behaviours of individuals either enhance or detract from aggregate stocks. Logic dictates that the ability to establish and maintain social capital is beyond any single individual's control (Messer, 1998); yet, this important resource greatly affects the perceived quality of individual lives (Coleman, 1990). Life is deemed easier 'in a community blessed with a substantial stock of social capital' (Putnam 1995, 66), and the resource makes possible 'the achievement of certain ends that in its absence would not be possible' (Coleman 1988, S98). Social capital constitutes an important asset 'that can be called upon in a crisis' (Woolcock 2001, 67) and 'the more extensively persons call on one another for aid, the greater will be the quantity of social capital generated' (Coleman 1990, 321). Accordingly, social capital is not depleted by use, unlike financial capital. Theory predicts that social capital which is 'bonding' in nature is found in groups of like-minded people; it acts as a kind of sociological 'superglue' and is good for 'getting by' (Putnam 2000).

Religion is a potent, long-lasting source of social capital (Greeley 1997) and religious congregations are among the key producers of social capital at local level (Ammerman 1997; Putnam 2000). Social capital has been studied among the communities of rural churches and cathedrals (Francis and Williams 2015; Ineson and Burton 2005), but not yet among rural clergy.

\section{The contribution of action learning to social capital}

Primarily, action learning tends to be goal-driven, with measurable targets. Nonetheless, a secondary -almost incidental- reward is yielded by the pedagogical process. Theory and 
practice suggest that the reward comes about because the obligation to share experiences through collegial conversation and interaction builds networks (Raelin and Coghlan 2006). With typically four to six participants, sets enable learners not only to build a rapport and understand each others' working situation and inherent challenges, but also to generate the trust fundamental to open and honest discussion (Stephens and Margey 2015). The generation of social capital via action learning is consistent with Coleman’s $(1990,317)$ assertion that most forms of social capital are created 'as a by-product of other activities', arising without anyone willing the resource into being. Such incidental social capital contrasts with what has been termed fiat social capital, willed into being by a sponsoring organization that adopts an instrumental approach to the social structure (Muskett 2015).

In his conceptual history of social capital, Farr (2004) distinguished between employing social capital as a concept and as a term. Usage was traced back to the eighteenth and nineteenth centuries: Tocqueville, Hume, Smith and Mill displayed the concept without the term; while Buchanan used the term in 1995 without the concept. This distinction is evident in studies of action learning's contribution to social capital. Antell and Heywood (2015) utilized the discourse without the term in an evaluation of action learning in a global drinks manufacturing company, for which empowering the diverse and geographically dispersed workforce was a major challenge. Feedback from participants indicated that action learning sets had 'a glue effect' linking managers together, and that each was 'an effective tool not only for learning, but also for facilitating networking' (91). By contrast, Roberts and Roper (2011) employed the term in their study of a health-care system in the U.S., showing that the collaborative nature of action learning helped foster social capital through the enhancement of connections and creation of shared understanding, and that networks forged through action learning continued even after the relevant programme finished. Pedler and Attwood (2011) also used the term in their assessment of the contribution of action learning 
to social capital in the UK NHS Pathology Services. The peer relationship in sets was novel for many pathologists employed in a service where it is usual to work alone or just in small teams. For one participant, the set became like family, 'people you can trust and work with' (33). Sets matured into networks, with members telephoning each other between meetings; and people who had no contact with each other prior to the programme were in regular email contact.

Against this background, our case study aims to explore whether action learning for isolated rural clergy can establish a peer support network by generating bonding social capital among set members, which may endure beyond the life of the set, thus contributing towards the amelioration of the burden of isolation in rural ministry. The opportunity arose to address this research question through analysis of qualitative data collected as part of a larger project to evaluate a diocesan-wide ministry development programme in Cornwall (known as Accompanied Ministry Development or AMD, and sponsored by the Church of England Diocese of Truro), which featured action learning for clergy participants.

\section{The Diocese of Truro}

The Anglican Diocese of Truro in the far south-west of England is almost coterminous with Cornwall, which is surrounded by sea on all flanks save the Devon border. This is a predominantly rural region, with high poverty levels and a sense of independence. 'There are no motorways in Cornwall and once over the River Tamar it feels a long way from the rest of England,' wrote Barley (2015) introducing her study of the diocesan cathedral's ministry; 'London is five hours by train and transport by plane is far from reliable because of the frequent sea fogs' (404-5). Covering 1,390 square miles, with a population of 540,000 and a density of 390 persons per square mile, the diocese is one of the least populated in the Church of England (ranked 38 of 43) (Archbishops’ Council 2014). The diocese has one of the 
smallest Christian populations of all the Church of England dioceses (ranked 41), and church attendances there (Sunday, weekly, and at festivals) declined faster over 2009-13 than in the rest of the Church (Archbishops' Council 2014). The diocese is committed to 'Discovering God's Kingdom, Growing the Church.'

\section{Programme design}

Against this backdrop, the diocese invested in AMD, which aims 'to encourage Christian communities to flourish’. Between 2014 and 2018, all incumbent clergy of the diocese and the parishes in which they minister take part (grouped into seven Cohorts of 12). Because the diocese recognizes that different churches will flourish in different ways, the programme seeks to accompany rather than direct them.

To achieve its ends, AMD focuses on five themes which form the core subject matter of five four-day residential Clergy Colleges and parish activities in the formative first year. At this stage, each priest is accompanied by his/her own AMD Advisor and the pair meets regularly, in particular to reflect upon the Colleges. After the College-phase, a Bishop’s Conference agrees plans for future activity in parish, and the central diocesan team supports the implementation of parish projects.

\section{Action learning in AMD}

An overarching aim of AMD is to create effective learning communities within the Colleges, where clergy are not simply recipients of learning but are also tutors of each other, exchanging good practice. Action learning -a distinctive feature of the residential element of AMD- is an important vehicle to achieve this. It is notable that the account of an action learning initiative within another organization in Cornwall -the County Council's Children's Social Work and Psychology Services- revealed that the pedagogical approach has the 
capacity to support a learning community and forge professional networks in the county (Abbott and Mayes 2014).

Each period of residence in AMD begins (Monday) and ends (Thursday) with an Action Learning Group (as the sets are known), facilitated discussions usually lasting one and a quarter hours between six clergy that helps link Clergy Colleges with parish life. Two action learning sets run in parallel for each Cohort. Over a period of approximately nine months, a set meets on a total of 10 occasions, each time typically following the popular format for meetings with rounds for catching up, agenda setting, progress reports and review (Pedler 2008, 31-2). A variety of problems is brought to the sets: some related to ministry and aspects of church or parish life, others directly related to elements of the AMD programme.

Colleges were designed so that the sets, together with three Bible Reading sessions, periods of Reflection, and informal conversation, complement taught sessions and facilitate substantial peer reflection, support and learning. The 30-minute daily morning Bible Reading sessions are conducted in groups comprising the same members as the sets (without facilitation).

An outline of the programme shared with diocesan clergy during the consultation process prior to the launch stressed that 'participation in small Action Learning Groups will offer ongoing mutual support'. Systematic clergy feedback in 2013 on the proposal indicated that sets would be 'key to the whole process', important in relation to group cohesion and personal needs. An information sheet distributed to AMD staff and participants expresses the hope that the sets may 'decide to continue beyond the life of the programme and/provide a model for future ways of working between clergy'.

Whether such aspirations are attainable may depend to a large extent on how well the cohorts and action learning sets gel. Set membership (which is not self-selected) includes 
both female and male clergy, and typically encompasses a mix of ages, marital status and family situations. Priests relatively new to ministry and/or the diocese will find themselves in sets alongside more experienced priests and some nearing retirement; and there will be a mix of parish types and church tradition / theology (which has the potential to inhibit certain members). Sets typically include members from different parts of the diocese so at one extreme members could live, say, one hundred miles apart. Each set's facilitator is drawn from a pool of AMD facilitators, some female, some male; and he/she remains with his/her set throughout the process.

\section{Method}

\section{Procedure}

The case study ran from March 2015 to April 2016, when 47 semi-structured interviews (typically lasting between 30 and 60 minutes each) were conducted as part of the larger project. The interviewees comprised 32 clergy participants (drawn from several Cohorts and sets, at different stages of the programme) and 15 members of staff (10 Advisors, and 5 set Facilitators). All interviews were digitally recorded (with the appropriate protocol followed and interviewee consent forms signed beforehand). Participants' anonymity was assured, so biographical data were subsequently redacted from the transcripts.

\section{Analysis}

The research design was constrained by the programme structure, the availability of interviewees and their willingness to talk about their experience of action learning sets. All interviewees agreed to have interviews recorded, allowing transcripts to be produced. The expression of isolation or social capital was not confined to a few key phrases or words that could easily be identified and quantified, so manual content analysis was the best way of 
interrogating transcripts. Transcripts were read through and all sections that referred to relevant themes were coded according to whether they referred to the following:

(1) Sense of clergy isolation.

(2) Networks and norms in sets (e.g. collegiality).

(3) Social trust in sets.

(4) Readiness of set members to connect beyond Clergy Colleges (face-to-face or electronically).

(5) Reasons not to capitalize on social capital in sets.

On the basis of definitions of social capital discussed above, reports under (2) and (3) were treated as markers of the resource in the sets.

Rather than quantify results, which would detract from the content of references, we have used exemplar quotations to mark key ideas that were evident in the transcripts.

\section{Results and discussion}

\section{Sense of clergy isolation}

Isolation was a recurring theme at interview, supporting findings elsewhere about the experience of scattered rural clergy. One priest explained: 'we are a small diocese, which is big geographically. So, my nearest colleague is 20 miles away in each direction'. Another said: 'some other people can be really quite lonely in their ministry'. A third summed up the debilitating experience:

Being a parish priest is quite an isolated thing. You're surrounded by people a lot of the time, but you are still very much a lone person doing a job, and a lot of what you do nobody ever sees except you. Different people see different bits of it. And also geographically, this has always been known to be an isolated area, so you don’t get to see your colleagues very often ... All of that can lead to you just sort of sliding down a slope. 
Bemoaning that clergy are 'on their own', an advisor said: 'If you never get to see anyone, you can’t really blame them if they go slightly off-track... You're left to it as a vicar. No-one ever comes and says why are you doing that? Whereas in... other lines of work, you're constantly working alongside people.'

These extracts suggest that little has changed since Paul's (1964) landmark report for the Church on the deployment of clergy, where survey data in a chapter of the report devoted to clergy isolation revealed a pattern of over-extension, the problem of distances, the melting away of social support for the rural priest, intellectual and cultural isolation, a loss of heart when ministering to tiny congregations week-by-week, and breakdowns (83-86). ““To whom can I speak?” they often cry’ wrote Paul (137). Another quotation used by Paul encapsulated the vital need for peer support: 'We have no one to whom we can turn... Fellowship is a word much bandied about in the Church, but the substance of it barely exists’ (86).

For today’s clergy in the Cornish peninsula, face-to-face support from family members in other parts of the U.K. may not be readily accessible; and the county's geographical remoteness renders it hard for the diocese to recruit clergy. A staff member said: 'We have very few people who apply for jobs here. Even places that you would think to be very attractive... The perception is that you're a long way from your family'. Another said: 'There have been clergy that have... got to the interview and said: I'm sorry, I can't do this. My family live too far away’.

\section{Networks and norms in sets}

Interviews revealed many positive reactions to the opportunities for collegiality and networking offered by action learning. This was in stark contrast to the general experience with colleagues in ministry, as one priest suggested: ‘The clergy ... there’s not a lot of collegiality’. Another priest spoke about finding the chance to engage with peers in the set 
‘incredibly valuable’ and 'brilliant' and continued: ‘There’s that kind of collegiality... being able to say how it is, and actually maybe grow in those groups as well'. A third priest did not expect to become close friends with peers in the set, but nonetheless benefitted from the exchange of ideas on their problems:

It's been very interesting, and things that they have said, I’ve gone: Ooh! I could do that in my parish; or, you know, the answer to your question is so and so. We've helped each other, but not bosom buddy type things... because we haven’t chosen to be together.

A fourth priest assessed the impact of set membership this way:

That particular group has been obviously a huge positive as far as I'm concerned. Hugely helpful... to meet with fellow clergy from across the diocese. As it happens, our group has become quite intimate... Confidences are shared at a fairly deep level. And, I think all of us have expressed the fact that this has been perhaps the biggest positive so far, the biggest tangible positive of the programme.

A fifth priest contrasted the set with deanery chapter:

The little group ... we're all very different. Yes, I think it’s been very good... In fact ... I said in the group ... I felt closer with colleagues here than I felt in the chapter that I've been in many years, at times... I think we’ve just gelled together very, almost naturally, immediately. A sixth assessed the set as follows: 'It's just been really lovely. Meeting people who've got parishes and getting to know about their situation... Although we belong to a chapter, we have very different roles and not many people actually attend the chapter'. Yet another priest suggested the sets offered a blueprint for chapters: 'It is a lesson about doing something that perhaps deaneries were always meant to be.'

It was evident from data that the three 30-minute Bible Study sessions per College (in groups with the same membership as the sets) contributed to collegiality despite the facilitator's absence. As an alternative mechanism to stimulate discussion, Bible passages were facilitative. Written feedback gathered by the diocese at the end of a fifth College 
included the following comments: 'People ... like the bible study that happens without external input', 'The sessions without the stimulus of a Bible passage were less useful despite the presence of a facilitator' and 'Got to know each other well enough to enjoy pooling our insights about the Bible passages'. When asked at interview whether the overall number of action learning sessions was adequate, one priest indicated that Bible Study was regarded as an extension of action learning. Asked a similar question, another priest said:

I think it's about right, because the same groups meet in Bible Study in the morning. Often things that are perhaps going round ... coming to the surface for us, rather than having a normal Bible Study, I think that kind of process of integration is happening. There's a bit of plaiting going on.

\section{Social trust in sets}

Describing an intention behind the sets, a facilitator stressed the importance of members' developing confidence and trust in their peers:

It's about trust... It's about being open to people in the group and not writing them off before they've even listened to what they have to say... we all do it, let's face it.... It's about them being able to voice and hear themselves voice some of the things that perhaps they don't want to face or are uncertain about or threatened by ... and I would hope that they would keep the confidentiality of that space.

Interview data suggest that this aspiration was achieved. One of the clergy participants explained: 'Yesterday morning... I found myself sharing something quite profound. I said: Oh, I hadn’t expected to say that... But then it sparked others to open and we all found ourselves in a similar boat... People have been very honest'.

Contrasting the set with deanery chapter, another priest said: 'I would say we have found a kind of trust and benefit from sharing with one another that we've never encountered within chapter meetings'. A further priest attributed the social trust in the set to the fact that 
that membership was drawn from different deaneries: 'I guess what some of us felt was there's more honesty in this group because we're not from the same deanery; there's no sort of hidden agendas about stuff that we might be grappling with locally’.

Another set facilitator summed up the process:

I think there is something about them having the opportunity to talk to each other and to build real trust. And interesting at the end of last session and again this morning people were saying, and looking each other in the eye and going: Actually, I trust you. I'll say something here that I wouldn’t say anywhere else.

\section{Readiness of set members to connect beyond Clergy Colleges}

A staff member expected that the resource built in the sets could be drawn upon in future: 'You... set up a possibility of when you go away, you actually ring your friend up and say this has happened, you know, can you help me?' So, was this expectation realized? The evidence gathered so far suggests that the networks, norms and social trust were significant for some participants, especially as a source of assistance in future.

One priest explained:

I think probably the links that have been made will mean that people will be happy to ring others up, if they needed help. [The level of trust is such] that I'm quite sure they'd kind of think: Oh, yes, I could ring her up or him up.

Another priest envisaged co-ordinating the support of the full set membership in response to a plea for help:

I found a lot of common ground. We're very different, but a lot of common ground. And if that person rang me up and said 'I've got a problem, I’m not quite sure. I need a coffee', I would drop everything, but also immediately get hold of the other members of the set (having checked first that I could) and say: This is important. 
Asked whether a face-to-face meeting outside the confines of a Clergy College might be contemplated in such circumstances, the priest said: 'I would. I would. If the occasion [arose] that would be my first port of call. I can't think of anybody, anybody else to be honest that I would trust'.

For one priest who did not rate the action learning initiative especially highly, a peer network was facilitated by links forged during the informal conversations and scheduled periods of reflection which complemented the action learning. This individual expected to connect with AMD Cohort colleagues both electronically and face-to-face:

This afternoon, going for a walk together. I now know these people. And I can phone around the diocese. Oh, I’ve got this idea, this problem. Go and have a talk with somebody about it. So, I think that's been really helpful.

This serves as a reminder that sets are not stand-alone activities in AMD. Sets take place within a context where colleagues are resident at four-day Colleges and together eat, socialise, reflect, study, and listen to input from diocesan staff and visiting speakers. Social capital built otherwise through Colleges is likely to facilitate and enhance the trust and networks formed in sets.

One of the advisors worried that staff had given insufficient attention to the question of how to conclude the College phase of action learning satisfactorily. The advisor suggested that each set should 'have an agreed plan about how they would like to take the group forward'. It was clear that some sets had begun to think about this. A priest reported that their facilitator had extended an invitation to meet again: 'Our facilitator... offered that... and those who did say something, they said: Yea, it would be great if you could do that.' A priest from another set said it hoped to meet again, but observed that turnover would cause natural attrition in set membership: 'We might get together once or twice a year perhaps. I don’t know how long that will continue, because people will come and go’. Another priest was keen for a set to meet again, but circumspect about the time commitment involved: 
We did mention this in our group this morning that it would be nice to continue to meet. I don't know how many times and where - somewhere central... I'd be happy to do that. I wouldn't be able to commit myself to frequent meetings, but an occasional one. Sometimes we all say, for the best of reasons, it would be lovely to keep in contact, we will - but it doesn’t always happen, does it.

A facilitator declared a longing for the establishment of formal peer support groups within the diocese: 'I would like to see clergy support groups set up after Clergy Colleges. They do them informally, if in their little Action Learning Groups they want to meet again, but I would like the diocese to actually set them up formally’2. The facilitator continued: 'To have their peer group saying: Have you thought about, or I wouldn't do that, or you're stupid. Because peers can say that to you. So that's what I would like to see'.

\section{Reasons not to capitalize on social capital in sets}

Data revealed two reasons for priests not intending to capitalize on social capital in action learning sets. The first such reason was individual differences. When asked about the likelihood of a set maturing into a peer support network, one priest responded: 'I don’t envisage [set members] being continued support for me, because we're so disparate in terms of geography and churchmanship and experience'. The fact that set members were scattered around the diocese appeared to be an insurmountable obstacle and there was no mention of the potential for electronic communication among set colleagues to relieve isolation in that individual's case. An advisor was also aware of distance between members being a possible obstacle: ‘they're all from different geographies' was the lament. Nonetheless, the advisor recognized one crucial advantage in the geographically dispersed set memberships:

If they've just got their mates from across the other parish, it becomes a bit too matey really.

So, the networking opportunities improve ... you have the opportunity potentially if you 
really get to know someone well, of having somewhere to go and have a confidential and open conversation with someone from a parish way-away.

Aside from individual differences and dispersed memberships, the second deterrent to forming and/or exploiting social capital in sets was pre-existing support networks. Written feedback provided to the diocese by a priest at the end of a fifth College indicated that sets were 'quite a highlight of the residential', but the respondent added 'still not as good as the groups I pray and study with in my own parish'. At interview, a priest who rated the action learning set as 'very good' was unsure nonetheless whether ongoing support would emerge from that source:

I'm in a very good cell group of people I trained with, and we meet about twice a year... I can see [the set's] benefit whilst we go through AMD, for the two years. But then I guess, after that - what happens? ... And if it’s just about a group of clergy meeting to support each other, at this stage, and I may be proved wrong, later on - but at this stage, I tend to go: That's how I see my cell group.

Likewise, a priest in a different cohort was asked at interview whether a peer support group was forming within a set: 'No. No way'. The explanation was: 'I’ve got my own different people to support me in ministry’.

Predominant among the satisfactory pre-existing networks was deanery chapter. However, interviews revealed varying experiences of chapter meetings in deaneries. Clergy life was enhanced for those in locations where weekly gatherings offered the opportunity for deanery colleagues to meet, pray and talk together; whereas, as illustrated above, clergy elsewhere expressed disappointment at imperfect mutual support in that context. Again, similar shortcomings had been highlighted by Paul (1964), who stated that clergy were 'left too much alone, enjoying only tenuous contacts with other clergy' and needing to be drawn 'more closely together corporately' by a range of proposed initiatives including a minimum requirement of a monthly deanery chapter meeting, with worship and a meal (182-3). 
Some Truro diocese clergy reactions were in tune also with Platten’s (2005) article on the changing nature of ministry, in which he referred to Waugh's (1968) vivid depiction of a deanery chapter whose members were highly individual and competitive. At interview, one priest detected the competitive culture even at the first Clergy College, but felt it had dissipated by the second College and been replaced by a marked openness and willingness to share:

Last time... I just felt as if it was a load of clergy getting together to say what they haven’t done, who's the best and who's the worst... On the surface it probably wasn't like that, but that's what it felt like. I think now, people are a few more weeks into it, we're all in a better position than when we started. I think the first one, everyone’s trying to almost lay down their territory. Whereas in this one, people are going: Well, actually, I might just be open and honest and say it as it is.

Waugh's novel indulged in parody, but his 'chapter' chimes with the experience of clergy gatherings even beyond the U.K., from which ministers depart 'feeling vaguely dissatisfied and cynical, disturbed by how oddly competitive and condescending the meetings are and disappointed that in one way or another they had again missed a chance to offer one another support in ministry’ (Braudaway-Bauman 2012, 22). Platten (2005) pleaded for clergy to be more 'co-supportive’ and argued for a new approach to collegiality, with a system sufficiently flexible 'for new partnerships and links to be built' (248-9).

By establishing new links, and thereby creating potent bonding social capital, AMD action learning sets appeared to plug a gap left by deanery chapters that do not fulfil clergy expectations for mutual support. A facilitator suggested that one reason this can be achieved is the relative sizes of sets and chapters: 'The smallness of the group... six plus a facilitator, I think this is the right size, because you can build trust... that's why some chapters don't work, because they're too big'. Describing a round of group reflection about the merits of the action learning process, the facilitator said: 
We had a conversation this morning... because a number of them were saying how one of the things they [valued] most out of this process is just the coming together, and spending time with each other, and that supportive, nurturing group. Which I think is really positive. So I asked: don't you get that at chapter?

The response within the set was that clergy felt unable to talk at chapter meetings and drop their guard because of a perceived lack of confidentiality. This viewpoint was echoed by a priest in a portrayal of an action learning set: 'We certainly act as a little... support group, which is how we all hoped chapter would be.'

Supportive deanery chapter meetings were widely recognized as a blessing. Speaking of the opportunities presented by AMD, a second priest said:

It's really good to come away and reflect theologically, and to talk to people. I think I'm unique in that I do get that every week. If I didn’t get that, then I think I would be really excited about doing that. I would really appreciate that. And I do appreciate it. Don't get me wrong.

Contrasting an action learning set with deanery chapter, a third priest said:

[In the action learning set] you get to know people by name and you get to remember what they did how they are and one thing and another. And it is good to be able to... listen to what they have to say, and be able to get on board with where they're at as well. And perhaps support them as they support you. But one of the things that we're quite fortunate in our deanery is that we have weekly chapter meetings. We meet weekly, pray weekly, we Bible Study weekly... it works well.

\section{Concluding remarks}

Against the background of studies of isolation among rural clergy, of findings of a natural tendency for such clergy to prefer introversion over extraversion, and also of a claim that action learning has the potential to ameliorate the burden of isolation, this case study focused 
on action learning for clergy in the rural Diocese of Truro. Interviews revealed a real sense of isolation among some clergy (echoing Church findings more than 50 years ago); and concerns were articulated by diocesan staff about the impact on individual priests and the organization’s capacity to fill vacant posts.

In evaluating a development programme which is innovative in that it seeks to accompany ministers, it is intriguing that Revans (2011) used the word 'companions' to describe the relationship between set members (15), and that one definition of action learning includes the notion of tackling problems ‘in the good company’ of others (Simpson and Bourner 2007, 184). It was evident from interviews with facilitators and AMD participants alike that their sets comprised good companions. The action learning sets are an element of the overall programme where accompaniment is palpable and valued by participants. Social capital generated otherwise at residential Colleges (through interaction at mealtimes, in Bible reading sessions and during free time) is likely to promote the formation of the resource within the facilitated sets. We therefore recommend that those who plan action learning interventions, whether in the church or other settings, give thought to organizing occasional opportunities for participants to socialise together, outside the confines of their set: such social interaction may prove to be a catalyst for the generation of valuable social capital back in the set. Yet, the bonding social capital formed in the sets described here appears to be highly distinctive. A remarkable amount of trust was built up through a marked openness and vulnerability among participants, and their willingness to share struggles and pains of ministry. This appears a type of social trust not necessarily generated within all deanery chapters in the diocese, where there may be a lack of confidentiality, and where a hallmark of the culture may be competitiveness. The fact that AMD action learning sets were confidential and facilitated by people independent of the deanery hierarchy was likely to have 
meant that members quickly realised that the process offered a trustworthy space in which to tackle problems, where any temptation to hide behind a professional guise could be avoided.

The trust, norms and networks formed via action learning created a resource upon which priests can draw, as the need arises. As in the NHS Pathology Services (Pedler and Attwood2011), the outcome was readiness to connect with set colleagues by telephone and/or face-to-face for support: the bonding social capital generated in the sets was evidently propitious for 'getting by'. Although some priests said they would respond with alacrity to set members in a crisis, others already well supported in their locality or otherwise (for example, by deanery chapter) saw no reason to capitalize on such bonding social capital. There was also a sense that individual differences among set members and distance between them could pose insurmountable barriers to forging social capital via the pedagogical process. Yet, even though geographically scattered set memberships militated against continuation, they also presented opportunities to consult a trusted confidant in a parish far distant from the priests' own. Indications are that the ambition of the diocese that sets continue beyond the life of AMD and/or provide a model for future ways of clergy working is being fulfilled in some way at least for some members. The ongoing project to evaluate the AMD programme is collecting additional qualitative and quantitative data that may in the future shed further light on the relationships between action learning, social capital and outcomes in parishes.

As a resource that can arise without anyone’s command, social capital can go unrecognized and tends to be 'taken into account in social research [less] than its intangible character might warrant' (Coleman 1990, 318). The significance of this case study is that it is the first account of social capital formation among rural clergy many of whom are challenged by a sense of isolation. It also contributes to knowledge as the first account of the practice of action learning with clergy. 
The authors would like to thank St Luke’s College Foundation (UK Registered Charity 306606) who funded the project to evaluate the Accompanied Ministry Development programme in the Diocese of Truro. Grateful thanks are also expressed to the staff of the Diocese of Truro and participants in the programme.

1. Deanery chapters are long-standing contexts, regarded in the nineteenth century as clerical assemblies to emulate those of other professions (D. Williams 2007). In the Diocese of Truro, there are 12 deaneries of various sizes, the smallest number of parishes being 9 and the largest 27.

When the current Bishop of Truro was new to the diocese, he visited all deaneries and encouraged them to meet weekly in chapter to pray together, read the Bible and plan. Weekly chapter meetings were discretionary and a small number of deaneries took up the idea.

2. A 'Work Based Learning Groups' initiative was launched by the Diocese of Truro in 2011 (Vaughan-Wilson 2016), inspired by Balint groups within the NHS (see Salinsky 2009 and, for example, Travis 2008 on a Balint-style group initiative in the Bristol Diocese). There was no prior history of such peer support groups in the diocese. Members were invited to join the first WBLG by the Bishop. Two further WBLGs met over the succeeding two years. Each WBLG, comprising 6-8 clergy, had two professional, paid facilitators. Each WBLG lasted two hours and met over 8 weeks. Regular attendance was a requirement; and this was mostly successful. The initiative halted as preparations were made for action learning sets within AMD. Now self-facilitated, the first WBLG continues to meet. 


\section{References}

Abbott, C., and C. Mayes. 2014. “Action Learning for Professionals: a new Approach to Practice.” Action Learning: Research and Practice 11(1): 72-80.

Ammerman, N.T. 1997. Congregation and Community. New Brunswick: Rutgers University Press.

Antell, S., and J. Heywood. 2015. "Exploring the Challenges in Scaling up the Delivery of Action Learning Facilitator Training with a Global Organization.” Action Learning: Research and Practice 12: 85-98.

Archbishops’ Council. 2011. The Changing Role of Deaneries. GS MISC 984. https://www.churchofengland.org/media/1283676/gs\%20misc\%20984.pdf

Archbishops’ Council. 2014. Statistics for Mission 2013. https://www.churchofengland.org/media/2112070/2013statisticsformission.pdf

Barley, L. 2015. “Truro Cathedral: Spires of Hope on the Duchy Peninsula.” Theology 118: 404-412.

Braudaway-Bauman, C. 2012. “Peer Power. The Promise of Clergy Support Groups.” Christian Century: 22.

Bourdieu, P., and L.J.D. Wacquant. 1992. An Invitation to Reflexive Sociology. Cambridge: Polity Press.

Brehm, J., and W. Rahn. 1997. "Individual-level Evidence for the Causes and Consequences of Social Capital.” American Journal of Political Science 41: 999-1023.

Church of England. 2014. Talent Management for Future Leaders and Leadership Development for Bishops and Deans: A New Approach. London: Church of England. https://churchofengland.org/media/2130591/report.pdf

Coleman, J.S. 1988. “Social Capital in the Creation of Human Capital.” The American Journal of Sociology 94: S95-S120. 
Coleman, J.S. 1990. Foundations of Social Theory. Cambridge, MA: Belknap Press.

Cornies, D. 2014. Leadership Development: the Top Five Dioceses. London: Archbishops' Council.

Eatock, J. (1993). Facelift for a Deanery Chapter. Banbury: Parish and People.Eysenck, H.J. and Eysenck, S.B.G. 1991. Manual of the Eysenck Personality Scales. London: Hodder and Stroughton.

Farr, J. 2004. “Social Capital: A Conceptual History.” Political Theory 32: 6-33.

Francis, L.J., and C. Brewster. 2012. "Stress from Time-Related Over-Extension in MultiParish Benefices.” Rural Theology 10: 161-178.

Francis, L.J., P. Laycock, and C. Brewster. 2015. “The Burdens of Rural Ministry: Identifying and Exploring the Correlates of Five Causes of Stress among Rural Anglican Clergy serving in Multi-Parish Benefices.” Research in the Social Scientific Study of Religion 26: 218-236.

Francis, L. J., Smith, G., \& Robbins, M. 2004. “Do introverted clergy prefer rural ministry?” Rural Theology 2: 127-134.

Francis, L.J., and E. Williams. 2015. “Cathedral Congregations: Retreating from Commitment or Generating Social Capital.” In Anglican Cathedrals in Modern Life. The Science of Cathedral Studies, edited by L.J. Francis, 51-72. New York: Palgrave Macmillan.

Greeley, A. 1997. “Coleman Revisited. Religious Structures as a Source of Social Capital.” The American Behavioral Scientist 40: 587-594.

Halpern, D. 2005. Social Capital. Cambridge: Polity Press.

Ineson, K., and L.M. Burton. 2005. "Social Capital Generated by Two Rural Churches and the Role of Individual Believers.” Rural Theology 3: 85-97. 
Lorenzen, M. 2007. “Social Capital and Localised Learning: Proximity and Place in Technological and Institutional Dynamics.” Urban Studies 44: 799-817.

Messer, J. 1998. “Agency, Communion, and the Formation of Social Capital.” Nonprofit and Voluntary Sector Quarterly 27: 5-12.

Moss, D. 2009. “On being ‘non-residential’”. Theology CXII: 344-352.

Muskett, J.A. 2015. "Building associations among cathedral Friends. From topophilia to fiat social capital?” Research in the Social Scientific Study of Religion 26: 57-76.

Muskett, J.A. 2016. “From Action Learning to Bonding Social Capital? The Potential of Action Learning Sets among Isolated Rural Clergy.” Rural Theology 14: 25-43.

Nahapiet, J., and S. Ghoshal. 1998. "Social Capital, Intellectual Capital, and the Organizational Advantage.” Academy of Management Review 23: 242-266.

Newton, K. 1999. “Social Capital and Democracy in Modern Europe.” In Social Capital and European Democracy, edited by J.W. van Deth, M. Maraffi, K. Newton and P.F. Whiteley, 3-24. London: Routledge.

Pahl, R. E. 2000. On Friendship. Cambridge: Polity Press.

Paul, L. 1964. The Deployment and Payment of the Clergy. London: Church Information Office.

Pedler, M. (2008). Action Learning for Managers. Burlington, VT: Gower.

Pedler, M., and M. Attwood. 2011. “How can Action Learning Contribute to Social Capital?” Action Learning: Research and Practice 8: 27-39.

Platten, S. 2005. “Inductive Formation. Theological Education and the Changing Nature of Ministry.” Theology 108: 243-253.

Portes, A. 1998. “Social Capital: Its Origins and Applications in Modern Sociology.” Annual Review of Sociology 24: 1-24. 
Putnam, R.D. 1995. “Bowling Alone: America’s Declining Social Capital.” Journal of Democracy 6: 65-78.

Putnam, R.D. 2000. Bowling Alone: The Collapse and Revival of American Community. New York: Simon and Schuster.

Putnam, R.D., and K.A. Goss. 2002. “Introduction”. In Democracies in Flux, edited by R.D. Putnam, 3-19. New York: Oxford University Press.

Raelin, J.A., and D. Coghlan. 2006. “Developing Managers as Learners and Researchers: Using Action Learning and Action Research.” Journal of Management Education 30: 670-689.

Revans, R. 2011. ABC of Action Learning. Farnham: Gower.

Roberts, C., and C. Roper. 2011. “The Four C’s of Leadership Development.” In Organization Development in Healthcare: Conversations on Research and Strategies, edited by J.A. Wolf, H. Hanson, M.J. Moir, L. Friedman and G.T. Savage, 125-149. Bingley: Emerald Group.

Rolph, J., T. ap Siôn, L.J. Francis, and P. Rolph. 2014. "Stress in Rural Ministry: Listening to Anglican Clergy in England.” Rural Theology 12: 106-118.

Salinsky, J. 2009. “A very short introduction to Balint Groups.” The Balint Society. http://balint.co.uk/about/introduction/

Simpson, P., and T. Bourner. 2007. "What Action Learning is not in the Twenty-First Century.” Action Learning: Research and Practice 4: 173-187.

Staley, R.C., M.R. McMinn, K. Gathercoal, and K. Free. 2013. “Strategies Employed by Clergy to Prevent and Cope with Interpersonal Isolation.” Pastoral Psychology 62: 843-857. 
Stephens, S., and M. Margey. 2015. “Action Learning and Executive Education: Achieving Credible Personal, Practitioner and Organizational Learning.” Action Learning: Research and Practice 12: 37-51.

Travis, M. 2008. “Supporting clergy in postmodern ministry.” Practical Theology 1: 95-130. Vaughan-Wilson, J. 2016, 28 January. “ALGs - background in Truro Diocese.” Email message to J. Rowe, Truro.

Watt, L., \& Voas, D. 2015. “Psychological types and self-assessed leadership skills of clergy in the Church of England.” Mental Health, Religion and Culture 18: 544-555.

Waugh, A. 1968. Consider the Lilies. London: Michael Joseph.

Williams, D. 2007. "Parsons, Priests or Professionals? Transforming the Nineteenth-Century Anglican Clergy.” Theology 110: 433-442.

Williams, E. 2008. “Measuring Religious Social Capital: the Scale Properties of the Williams Religious Social Capital Index (WRSCI) among Cathedral Congregations.” Journal of Beliefs and Values 29: 327-332.

Woolcock, M. 2001. “The Place of Social Capital in Understanding Social and Economic Outcomes.” http://www.oecd.org/innovation/researchandknowledgemanagement/1824913.pdf 